\title{
Immediate Type Systemic Hypersensitivity Reactions After the Inactivated SARS-CoV-2 Vaccine in Healthcare Workers
}

\author{
Sağlık Çalışanlarında İnaktive SARS-CoV-2 Aşısı Sonrası Gelişen Ani Tip Sistemik Așırı Duyarlılık Reaksiyonları
}

${ }^{1}$ Pamir Cerci, ${ }^{2}$ Anil Ucan

${ }^{1}$ Department of Immunology and Allergy Diseases, Turkish Ministry of Health,

Eskişehir City Hospital, Eskişehir, Turkey

'Department of Internal Medicine, Turkish Ministry of Health, Eskişehir City Hospital, Eskişehir, Turkey

Correspondence:

Pamir PERÇI

Department of Immunology and Allergy Diseases, Turkish Ministry of Health, Eskișehir City Hospital, Eskişehir, Turkey e-mail: pamir.cerci@saglik.gov.tr

\section{Abstract}

The vaccines developed for Coronavirus disease 2019 (COVID-19) not only brought hope to the struggle against the pandemic but also raised questions about hypersensitivity reactions that might occur. Although some studies regarding these concerns with mRNA COVID-19 vaccines have been published, these data on inactivated Severe Acute Respiratory Syndrome Coronavirus 2 (SARS-CoV-2) vaccine are not available. The objective of this study was to determine the safety of the inactivated SARS-CoV-2 vaccine manufactured by Sinovac by evaluating the reported systemic immediate hypersensitivity reactions (IHRs) after the administration of the vaccine to healthcare workers (HCWs). This was a retrospective analysis of inactivated SARS-CoV-2 vaccine recipients in all HCWs vaccinated at our center. Relevant data of all patients who received the vaccine were collected from the electronic medical records available at our center's database. A statistical analysis of subjects who reported acute adverse reactions was conducted. Of the $3354 \mathrm{HCW}$ s vaccinated with the first dose (female 59.9\%, pre-existing allergic disorder $2.4 \%$ ), four acute adverse reactions $(0.12 \%)$ met the definition of a systemic IHRs were reported, and only one was confirmed to be anaphylaxis. One out of these four cases received her second dose through graded administration. For the second dose, no systemic reaction was reported in our study population. Inactivated SARS-CoV-2 vaccine appears to be well tolerated in HCWs without any pre-existing allergic disorders.

Keywords: Allergy; coronavac; covid-19; hypersensitivity; Turkey; vaccine

\section{Özet}

Koronavirüs hastalığı 2019 (COVID-19) için geliştirilen aşılar, pandemi ile mücadelede umut ışığı sağlarken bir yandan da oluşabilecek aşırı duyarlılık reaksiyonları hakkında soru işaretlerini de beraberinde getirmiştir. Yeni mRNA COVID-19 aşıları ile ilgili bu endişelere ilișkin bazı çalışmalar yayınlanmış olsa da inaktive Şiddetli Akut Solunum Yolu Sendromu Koronavirüs 2 (SARSCoV-2) aşıları ile ilgili veriler yaygın değildir. Bu çalışmanın amaç, aşının sağlık çalışanlarına uygulanmasından sonra bildirilen sistemik ani aşırı duyarlılık reaksiyonlarını (ADR'ler) değerlendirerek Sinovac tarafından üretilen inaktive SARS-CoV-2 aşısının güvenliğini belirlemektir. Merkezimizde inaktive SARS-CoV-2 aşısı ile aşılanan tüm sağlık çalışanlarını retrospektif olarak inceledik. Aşı yapılan tüm hastaların ilgili verileri merkezimizin veri tabanında bulunan elektronik tıbbi kayıtlardan toplanmıştır. Akut advers reaksiyonlar bildiren deneklerin istatistiksel bir analizi yapılmıștır. İlk dozla aşılanan 3354 sağllk çalıșanından (kadın \%59,9, önceden var olan alerjik durum \%2,4), sistemik ani tip aşırı duyarlılık reaksiyonu tanımını karşılayan dört akut advers reaksiyon $(\% 0,12)$ bildirilmiştir. Sadece birinin anafilaksi olduğu doğrulanmıştır. Bu dört vakadan biri ikinci dozunu dereceli uygulama yoluyla almıștır. İkinci doz için, çalışma popülasyonumuzda herhangi bir sistemik reaksiyon bildirilmemiștir. İnaktive edilmiş SARS-CoV-2 aşısı, önceden herhangi bir alerjik hastalığı olmayan sağlık çalışanlarında iyi tolere edilmiş gibi görünmektedir.

Anahtar Kelimeler: Alerji; aşı; aşırı duyarlılık; coronavac; covid-19; Türkiye;

Received 07.06.2021 Accepted 13.08.2021 Online published 23.08.2021 


\section{Introduction}

The pandemic caused by the Severe Acute Respiratory Syndrome Coronavirus 2 (SARSCoV-2) is a global public health concern which already took over two million lives and continues to threaten every individual on the planet earth. As of January 31, 2021, Turkey reported 2,477,463 confirmed cases of coronavirus disease-2019 (COVID-19) and 25,993 deaths (1). Vaccination, a miracle of modern medicine, has become the best chance to control this pandemic. After extensive study and work of devoted scientists, humanity now has numerous vaccines against the COVID-19. However, several questions arise regarding their safety. One of these questions focuses on the allergic potential of these vaccines. Although hypersensitivity reactions due to vaccines are not uncommon, systemic severe allergic reactions like anaphylaxis are rare $(2,3)$. A vaccine safety datalink study reported an incidence rate of 1.31 (95\% confidence interval, $0.90-1.84)$ The anaphylaxis cases per million doses and found that majority of these cases had pre-existing atopic diseases (4). Due to a possible hypersensitivity reaction, The Centers for Diseases Control and Prevention advised observation of all patients for at least 15 minutes and monitorization of patients with allergy history at least 30 minutes after vaccination (5). After the authorities' approval, two COVID-19 mRNA vaccines from Pfizer-BioNTech and Moderna have been used in several countries. Although the results of phase III trials showed that these vaccines were relatively safe after the initiation of the COVID-19 vaccination program, there were some reports of allergic reactions in the United Kingdom and the United States of America $(6,7)$. Most of these reactions were mainly attributed to the polyethylene glycol (PEG) component of these vaccines $(8,9)$.

CoronaVac, the vaccine developed by Sinovac Life Sciences (Beijing, China), is an inactivated SARS-CoV-2 vaccine created from African green monkey kidney cells and contains aluminum hydroxide as an adjuvant. Inactivation of SARS-CoV-2 is achieved with $\beta$-propiolactone (10). After the promising results of this vaccine in phase $1 / 2$ clinical trials, the Turkish Ministry of Health permitted this vaccine's applicationon14 January 2021 to be used in two specified doses at one-month intervals (10). The first group selected for vaccination included healthcare workers (HCWs). Because CoronaVac clinical trials excluded patients with known allergies, the question regarding the safety of applying this vaccine to allergic individuals remains unanswered (10-12). People with prior allergies may fear these side effects and step back for vaccination, which may result in a failure to reach the goal of aluminum. In our retrospective study, we evaluated the frequency of systemic immediate hypersensitivity reactions (IHRs) developed within the first two hours of the first and second doses of CoronaVac administration in $3354 \mathrm{HCWs}$. We aimed to determine its safety in individuals with a previous history of allergies or allergic reactions.

\section{Material and methods}

\section{Study Design and Population}

We performed a retrospective evaluation of CoronaVac administration to $3354 \mathrm{HCWs}$ between 18 and 65 years of age. The study included $80 \mathrm{HCWs}$ with pre-existing allergic diseases and 3274 HCWs without a preexisting allergic disease. All were vaccinated with CoronaVac $600 \mathrm{SU} / 0.5 \mathrm{~mL}$ at Eskisehir City Hospital. The data were collected from the hospital's electronic database and were recorded in terms of their demographic characteristics, past laboratory results, and post-vaccination symptoms. A systemic IHR after vaccination was defined according to World Health Organization and related literature, and anaphylaxis was defined according to World Allergy Organization (1315). Local reactions such as erythema and itching at the injection site were not included in this study. The clinical symptoms of each case were retrospectively evaluated according to the Brighton Collaboration case definition (BCCD) level (16). History of pre-existing allergic disease was confirmed by an allergy specialist for patients who had a positive skin prick test result (wheal $>6 \mathrm{~mm}$ ) or a significant allergen-specific immunoglobulin 
E (IgE) result $(>3.5 \mathrm{kUa} / \mathrm{L})$ or a history of an associated hypersensitivity reaction after the administration of a drug.

The study was approved by the Ethics Committee of the Faculty of Medicine at Eskisehir Osmangazi University (Decision No. 19, dated 09.02.2021).

\section{Vaccination Procedure}

All HCWs were voluntarily vaccinated via the intramuscular route in the area reserved for them in the hospital according to the recommendations of the Turkish Ministry of Health Vaccine Application Guidelines which included allocation of a separate area for vaccination, preparation of experienced staff, and an emergency response team, and observation of individuals with allergies for at least one hour after administration.

\section{Statistical Analysis}

In our study, qualitative variables were defined with absolute frequencies and percentages. The definition of quantitative variables was made using mean, standard deviation (SD). Categorical data are given as a percentage (\%). Shapiro Wilk's test was used to investigate the compatibility of the data for normal distribution. In the comparison of groups that do not conform to normal distribution, the Mann-Whitney $U$ test was used for cases with two groups. IBM SPSS Statistics 21.0 program was used in the application of the analyses.

\section{Results}

Between 14 January 2021 and 18 January 2021, 3254 and 80 non-allergic and allergic HCWs received their first doses of the vaccine. Within one month following the first dose, the second dose was administered to 3187 and 76 non-allergic and allergic HCWs, respectively. Demographic characteristics of the study group and the number of systemic reactions seen after the two doses of the vaccine are shown in Figure 1. Eighty of these patients had pre-existing allergic disorders diagnosed by an allergy specialist prior to the vaccination. The distribution of these disorders was as follows; allergic rhinitis $(n=32)$, chronic urticaria $(n=13)$, drug allergy to antibiotics $(n=9)$, HSR to non-steroid antiinflammatory drugs $(n=7)$, miscellaneous drug allergy $(n=5)$, latex allergy $(n=6)$, allergic contact dermatitis $(\mathrm{n}=3)$, allergic asthma $(n=3)$, venom allergy $(n=2)$. According to our database, a total of 4 systemic IHRs were reported and of these four patients, three had pre-existing allergic disorders. Characteristics of these cases are summarized in Table 1.

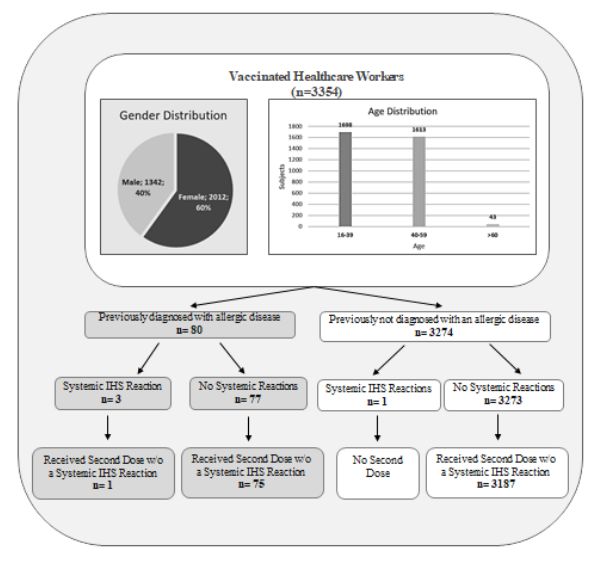

Figure 1. Characteristics of vaccinated healthcare workers and number of immediate hypersensitivity reactions

Figure Legend 1. This flow chart demonstrates the characteristics of the vaccinated healthcare workers. All 3354 patients received the first dose and 3263 received the second of the inactivated SARS-CoV-2 vaccine manufactured by Sinovac Life Sciences at the same health institution. Of all, 80 were patients with a previous history of allergist-diagnosed allergies. Of these 80 patients, 3 reported a systemic immediate hypersensitivity reaction. Only 75 out of 77 allergic patients and 3187 out of 3273 non-allergic patients who safely tolerated the first dose of the vaccine were vaccinated with the second dose. (w/o; Without, IHRs; Immediate Hypersensitivity Reactions) 
Table 1. Characteristics of cases of early adverse reactions following the first dose of CoronaVac administration $(\mathrm{n}=4)^{*}$

\begin{tabular}{|c|c|c|c|c|c|c|c|}
\hline \multirow{2}{*}{ No } & \multirow{2}{*}{$\begin{array}{l}\text { Age } \\
\text { (yrs.) }\end{array}$} & \multirow[t]{2}{*}{ Sex } & \multicolumn{2}{|c|}{ History } & \multirow{2}{*}{$\begin{array}{l}\text { Onset } \\
\text { (mins) }\end{array}$} & \multirow{2}{*}{$\begin{array}{l}\text { Signs and symptoms, Treatment } \\
\text { Setting and Outcome }\end{array}$} & \multirow{2}{*}{$\begin{array}{l}\text { BDDC } \\
\text { Levelब }\end{array}$} \\
\hline & & & Allergic Disorders $\dagger$ & $\begin{array}{l}\text { Previous } \\
\text { Anaphy. } \dagger\end{array}$ & & & \\
\hline 1 & 28 & $\mathrm{~F}$ & Chronic Urticaria & No & 60 & $\begin{array}{l}\text { Itchy hives and tachycardia. Symptoms disappeared } \\
\text { without treatment. Discharged home. Did not receive } 2^{\text {nd }} \\
\text { dose. }\end{array}$ & 3 \\
\hline 2 & 40 & $\mathrm{~F}$ & $\begin{array}{l}\text { Allergic Contact } \\
\text { Dermatitis, to Latex } \\
\text { and Nickel }\end{array}$ & No & 10 & $\begin{array}{l}\text { Generalized hives and respiratory distress. Recovered in } 3 \\
\text { hours at level } 1 \mathrm{ICU} \text {. Discharged home. Did not receive } \\
2^{\text {nd }} \text { dose. }\end{array}$ & 1 \\
\hline 3 & 29 & $\mathrm{~F}$ & Muscle Relaxants & No & 10 & $\begin{array}{l}\text { Urticaria and tachycardia. Recovered in } 3 \text { hours at level } 1 \\
\text { ICU, discharged home. The second dose was } \\
\text { administrated. }\end{array}$ & 3 \\
\hline 4 & 39 & M & No & No & 15 & $\begin{array}{l}\text { Generalized hives and a sensation of throat Treated at } \\
\text { level } 1 \text { ICU and recovered in } 2 \text { hours. Discharged home. } \\
\text { Did not receive } 2^{\text {nd }} \text { dose. }\end{array}$ & 2 \\
\hline & & $\begin{array}{l}\text { Anaphy. } \\
\text { * The pr } \\
\text { Was ac } \\
\text { T To det } \\
\text { The high } \\
\text { Levels } 2\end{array}$ & $\begin{array}{l}\text { naphylaxis; } I C U=\text { in } \\
\text { tion of this table was } \\
\text { ted positive if the pre } \\
\text { ine degrees of medic } \\
\text { degree of diagnostic } \\
3 \text { are successively lo }\end{array}$ & $\begin{array}{l}\text { sive care uni } \\
\text { pired by put } \\
\text { is history of } \\
\text { ertainty, the } \\
\text { fidence that } \\
\text { levels of dic }\end{array}$ & $\begin{array}{l}\text { nale; } M \\
\text { in the lt } \\
\text { or anap } \\
\text { Collab } \\
\text { led case } \\
\text { ertainty }\end{array}$ & $\begin{array}{l}\text { ale; } \text { No. }=\text { number; Yrs }=\text { Years } \\
\text { ture to provide visual integrity }(6,7) . \\
\text { xis were documented or confirmed by an allergist. } \\
\text { ion case definition (BDDC) uses combinations of symptoms. } \\
\text { ctually a case of anaphylaxis is defined by Brighton level } 1 .\end{array}$ & \\
\hline
\end{tabular}

The first patient (a 28-year-old female) was under evaluation for slightly elevated basal serum tryptase levels $(10.2 \mathrm{ng} / \mathrm{ml})$ and had chronic urticaria. She was under regular antihistamine treatment at the time of vaccination. After 1 hour of the administration, the patient reported itchy hives over her chest area and tachycardia, which resolved in a short time without any intervention. Her tryptase level during this reaction was $11.2 \mathrm{ng} / \mathrm{ml}$. This patient did not want to have the second dose of the vaccine.

The second patient (a 40-year-old female) was diagnosed with allergic contact dermatitis due to latex and nickel allergy, confirmed by a patch test. Ten minutes after the administration, she developed generalized hives and reported respiratory distress 10 minutes after the administration. Her examination revealed urticaria and rhonchi on osculation. She was immediately admitted to a level 1 intensive care unit (ICU) where she received $45.5 \mathrm{mg}$ of intravenous diphenhydramine and $80 \mathrm{mg}$ of methylprednisolone. No tryptase or any other blood study was performed. She was recovered within 3 hours and discharged home after 10 hours. This patient did not want to have the second dose of the vaccine.

The third patient (a 29-year-old female) was with a history of allergy to several muscle relaxants. Ten minutes after the administration, she developed urticaria and tachycardia. She was immediately admitted to the level 1 ICU and where she received 45.5 $\mathrm{mg}$ of intravenous diphenhydramine and 80 $\mathrm{mg}$ of methylprednisolone without further progression of symptoms. She was recovered in 3 hours. No blood sample was sent for tryptase level. The second dose of the vaccine was administered in graded doses under observation, and she tolerated it well without any symptoms. The protocol for graded administration is presented in Table 2.

Table 2. Protocol for graded administration of second dose of CoronaVac ${ }^{21,27}$

\begin{tabular}{ll}
\hline Step* & Dose and Concentration \\
\hline 1 & $0.05 \mathrm{~mL}$ of $1: 10$ vaccine dilution** \\
\hline 2 & $0.05 \mathrm{~mL}$ of full-strength vaccine \\
\hline 3 & $0.1 \mathrm{~mL}$ of full-strength vaccine \\
\hline 4 & $0.15 \mathrm{~mL}$ of full-strength vaccine \\
\hline 5 & $0.2 \mathrm{~mL}$ of full-strength vaccine \\
\hline
\end{tabular}


The fourth patient (39-year-old male) was the only case in our study group who was not diagnosed with an allergic disorder prior to the vaccination. He reported generalized hives and a sensation of throat closure after 15 minutes of the administration. His physical examination revealed urticaria. The patient was admitted to the level 1 ICU where he received $45.5 \mathrm{mg}$ of intravenous diphenhydramine and $80 \mathrm{mg}$ of methylprednisolone. His symptoms resolved in two hours, and he was discharged home. This patient did not wish to have the second dose of the vaccine.

\section{Discussion and conclusion}

In our study population, we found the frequency of patients who reported a systemic IHRs as $0.12 \%(n=4)$ for the first dose and zero for the second dose. However, only one met the criteria of anaphylaxis (13). Out of these reactions, two were observed in patients with a pre-existing allergic disorder, and only one of them gave consent for the second dose of the vaccine. This study provides evidence about using the inactivated SARS-CoV-2 vaccine produced by Sinovac Life Sciences (CoronaVac) in HCWs without pre-existing allergic disorders. Although CoronaVac was well tolerated in most of the patients, there are still many questions that need to be answered regarding reported allergic reactions.

Thanks to vaccination, one of the most valuable public health interventions, significant reductions have been observed in the spread and mortality of infectious diseases $(3,14)$. As with any other drug, allergic reactions can also be observed with vaccines but fortunately, most of them are not severe (17). Nevertheless, nowadays, when the whole world is preparing and even started vaccination programs with unprecedented intensity, allergic reaction to vaccines has come to the attention. Although only 21 vaccine-related adverse events were reported after administration of 1,893,360 doses of Pfizer-BioNTech COVID-19 vaccine, this finding of the possible allergic potential of COVID-19 mRNA vaccines has given ground to discussions (6). Some researchers suggested that PEG, an excipient in mRNA vaccines, may have a role in allergic reactions $(8,9)$. While there is no hard evidence proving PEG as the cause of reported allergic reactions, these discussions do not apply to CoronaVac because this vaccine does not contain PEG. The adjuvant in CoronaVac, aluminum hydroxide, is one of the most frequently used adjuvants in vaccines which is known to induce contact allergy and nodules at the injection site $(2,3)$. Because there is no aluminum hydroxide-related IHRs reported to date, we don't suspect the history of metal allergy as the cause for the anaphylaxis reported in our second patient (No 2.).

Published studies regarding the safety and tolerability of CoronaVac are limited. Two phase $1 / 2$ clinical trials done in China included a total of 923 patients who received a sum of 1838 doses and reported only two hypersensitivity reactions which only one was considered (a manifestation of urticaria) to be related to the vaccination $(10,12)$. As a result, the authors concluded that CoronaVac was well tolerated in adults aged 18 years and older. Since these studies included only healthy adults and excluded patients with known allergies, it may not be appropriate to compare their results with our study, which included 80 patients with pre-existing allergic disorders. A patient with a history of an allergic disorder may experience anxiety before vaccination and therefore may be unwilling to be vaccinated. In the literature, there are several studies and practice parameters advising not to exclude these patients from vaccination $(2,18-22)$. A study that included 478 children with asthma who were vaccinated with the live attenuated influenza vaccine reported that the vaccine was well tolerated (22). A phase 1 study that evaluated the safety of the smallpox vaccine in patients with atopic eczema and allergic rhinitis showed a good safety profile (23). In our study, a total of 32 patients with allergic rhinitis and 3 with allergic asthma were safely vaccinated with CoronaVac without reporting an IHR. More interestingly, there were six patients with allergist-diagnosed latex allergy in our cohort, and most of them tolerated the vaccine. Although the current Turkish package insert of CoronaVac does not indicate natural rubber latex in its tip caps on the 
prefilled syringe, in the vaccine vial stopper, and the needle cover, it is known that many vaccines contain dry natural rubber (DNR) latex (24). A review of more than 167,233 Vaccine Adverse Event Reporting System (VAERS) notifications reported only 28 patients that developed a possible allergic adverse event after receiving a DNR containing vaccine (18). The authors of this study concluded that vaccines that contain DNR are associated with minimal risk of IHRs. Unfortunately, our sample size is too small to come to such a conclusion. Still, we consider our finding valuable because our study is the first to evaluate the administration of CoronaVac to patients with latex allergy.

As the whole world prepares for massive vaccination, allergists will play essential roles in not only supporting the allergic patients to receive the vaccine but also in training the clinical staff conducting the vaccines about the management of anaphylaxis. A striking result of our study was to see that epinephrine administration was not considered to any of the patients that experienced systemic reactions. This may be due to the quick and good response of our patients to steroids, antihistamines, and inhale salbutamol. Nevertheless, we believe it would not be wrong to administer it to the second and fourth patients (No.2 and No 4.). Anaphylaxis is an acute, potentially life-threatening hypersensitivity reaction. While epinephrine is a vital therapy for recovering from anaphylaxis, a recent review that evaluated several studies have stated that it is underused (25). In a such time, when everyone is a candidate for COVID-19 vaccination, a possible challenge lies in avoiding overdiagnosing anaphylaxis as Greenhawt et al. mentioned in their editorial (26). A patient in our study reported cold and pale skin shortly after the injection which are characteristic symptoms for vasovagal reactions. We suggest that all the clinical staff working in vaccination should know the differences between an IHR and a vasovagal reaction in order to correctly classify the acute adverse reactions (2). Therefore, we consider that allergists' expertise will be needed even more in the days to come.
Our study had several limitations and some strengths. Firstly, the insufficient sample size for statistical measurement prevented us from suggesting any precise clinical implication. Since immediate reactions to vaccines, including COVID vaccines is rare, this sample size may be inadequate to draw significant conclusions. Secondly, our study group included only HCWs, which is quite a heterogeneous group in regard to disorders. This limitation is a result of the emergency use authorization giving $\mathrm{HCWs}$ prioritization in the vaccination program. Interestingly not all HCWs who safely tolerated the first dose were vaccinated with the second dose We lack the data on why these HCWs did not receive their second doses. Thirdly, the lack of tryptase analysis for all reported acute reactions made it difficult for us to interpret them. Also, since our study group was HCWs, a population not easily impressed by late or mild local reactions, we had to limit our study to systemic reactions developed in the first two hours. Lastly, when considering the typical prevalence of allergic diseases in our country $(7 \%-\% 20)$, it could have been expected that in a population of over 3000 people, there should have been at least 200 patients with known allergies. This resulted from our intention to make our database more reliable since we only accepted an individual as allergic if proven by an allergist; this may have impacted our sample size. The strengths of this study are that, to the best of our knowledge, this is the largest study documenting the tolerability of CoronaVac in a cohort that includes allergic patients and the first report documenting the safe administration of the second dose of CoronaVac through a graded dosing protocol. At the time in Turkey, the only available COVID-19 vaccine other than CoronaVac was the Pfizer-BioNTech vaccine. However, due to some concerns, our patient had she did not wish to be vaccinated with this vaccine. Therefore, we chose to vaccinate her with CoronaVac for the second time. Our graded dosing protocol has been adapted from the practice parameter about adverse reactions to vaccines which was published in 2012 (21). In a recent report, a similar protocol was safely used on two patients who experienced an IHR with the first dose of the Moderna COVID-19 vaccine (27). 
In our study, we evaluated the frequency of systemic IHRs after the first dose of CoronaVac administration to a total of 3274 non-allergic and 80 allergic HCWs. The second dose of the vaccine was administered to 3187 and 76 non-allergic and allergic HCWs, respectively. Our results suggest that CoronaVac was well tolerated in $\mathrm{HCWs}$ without pre-existing allergic disorders. The results of this research provide the first comprehensive assessment of the idea that patients with known allergies may be vaccinated by educated staff who are equipped to manage anaphylaxis. Further research would be helpful to determine the safety of CoronaVac administration in allergic patients.

\section{REFERENCES}

1. Turkish Ministry of Health COVID-19 Information Page: Turkish Ministry of Health; January 31, 2021 [Available at: https://covid19.saglik.gov.tr/EN-69532/generalcoronavirus-table.html]. Accessed March 1, 2021.

2. Nilsson L, Brockow K, Alm J, et al. Vaccination and allergy: EAACI position paper, practical aspects. Pediatr Allergy Immunol. 2017;28:62840.

3. McNeil MM, DeStefano F. Vaccine-associated hypersensitivity. $J$ Allergy Clin Immunol. 2018;141:463-72.

4. McNeil MM, Weintraub ES, Duffy J, et al. Risk of anaphylaxis after vaccination in children and adults. J Allergy Clin Immunol. 2016;137:868-78.

5. Control CfD, Prevention. Interim clinical considerations for use of mRNA COVID-19 vaccines currently authorized in the United States. [Available at: https://www.cdc.gov/vaccines/covid-19/clinicalconsiderations/covid-19-vaccines-us.html].

Accessed May 5, 2021.

6. Shimabukuro T. Allergic reactions including anaphylaxis after receipt of the first dose of PfizerBioNTech COVID-19 vaccine - United States, December 14-23, 2020. Am J Transplant. 2021;21(3):1332-7.

7. Team CC-R, Food, Drug A. Allergic Reactions Including Anaphylaxis After Receipt of the First Dose of Moderna COVID-19 Vaccine - United States, December 21, 2020-January 10, 2021. MMWR Morb Mortal Wkly Rep. 2021;70:125-9.

8. Banerji A, Wickner PG, Saff R, et al. mRNA Vaccines to Prevent COVID-19 Disease and Reported Allergic Reactions: Current Evidence and Suggested Approach. J Allergy Clin Immunol Pract. 2021;9:1423-37.

9. Cabanillas B, Akdis CA, Novak N. Allergic reactions to the first COVID-19 vaccine: A

\section{Acknowledgments}

We express our sincere gratitude to all the doctors, nurses, and personnel of Eskisehir City Hospital involved in vaccination for doing their duties devotedly. We also thank Muzaffer Bilgin, PhD, for statistical analyses, Reşat Kendirlinan, $M D$, for graphic presentations, and Sevim Bavbek, Prof. $M D$, for her gracious review of our manuscript.

\section{Authors' contributions}

A.U. and P.C.. contributed to the design and implementation of the research, the analysis of the results, and the writing of the manuscript potential role of polyethylene glycol? Allergy. 2021;76:1617-8.

10. Zhang Y, Zeng G, Pan $H$, et al. Safety, tolerability, and immunogenicity of an inactivated SARS-CoV-2 vaccine in healthy adults aged 1859 years: a randomised, double-blind, placebocontrolled, phase 1/2 clinical trial. Lancet Infect Dis. 2021;21:181-92.

11. Palacios R, Patino EG, de Oliveira Piorelli R, et al. Double-Blind, Randomized, PlaceboControlled Phase III Clinical Trial to Evaluate the Efficacy and Safety of treating Healthcare Professionals with the Adsorbed COVID-19 (Inactivated) Vaccine Manufactured by Sinovac PROFISCOV: A structured summary of a study protocol for a randomised controlled trial. Trials. 2020;21:853.

12. $\mathrm{Wu} \mathrm{Z}, \mathrm{Hu} \mathrm{Y}, \mathrm{Xu} \mathrm{M}$, et al. Safety, tolerability, and immunogenicity of an inactivated SARS-CoV-2 vaccine (CoronaVac) in healthy adults aged 60 years and older: a randomised, double-blind, placebo-controlled, phase $1 / 2$ clinical trial. Lancet Infect Dis. 2021;21:803-12.

13. Cardona V, Ansotegui IJ, Ebisawa M, et al. World allergy organization anaphylaxis guidance 2020 . World Allergy Organ J. 2020;13:100472.

14. World Health Organization. Regional Office for the Western Pacific. (2016). Immunization safety surveillance: guidelines for immunization programme managers on surveillance of adverse events following immunization. 3rd ed. Manila : WHO Regional Office for the Western Pacific [Available at https://apps.who.int/iris/handle/10665/208262]. Accessed May 1, 2021.

15. Marshall JS, Warrington R, Watson W, et al. An introduction to immunology and immunopathology. Allergy Asthma Clin Immunol. 2018;14(Suppl 2):49. 
16. Ruggeberg JU, Gold MS, Bayas JM, et al. Anaphylaxis: case definition and guidelines for data collection, analysis, and presentation of immunization safety data. Vaccine. 2007;25:567584.

17. Caubet JC, Ponvert C. Vaccine allergy. Immunol Allergy Clin North Am. 2014;34:597-613, ix.

18. Russell M, Pool V, Kelso JM, et al. Vaccination of persons allergic to latex: a review of safety data in the Vaccine Adverse Event Reporting System (VAERS). Vaccine. 2004;23:664-7.

19. Chung EY, Huang L, Schneider L. Safety of influenza vaccine administration in egg-allergic patients. Pediatrics. 2010;125:e1024-e30.

20. Greenhawt MJ, Li JT, Bernstein DI, et al. Administering influenza vaccine to egg allergic recipients: a focused practice parameter update. Ann Allergy Asthma Immunol. 2011;106:11-6.

21. Kelso JM, Greenhawt MJ, Li JT, et al. Adverse reactions to vaccines practice parameter 2012 update. J Allergy Clin Immunol. 2012;130:25-43.

22. Turner PJ, Fleming L, Saglani S, et al. Safety of live attenuated influenza vaccine (LAIV) in children with moderate to severe asthma. J Allergy Clin Immunol. 2020;145:1157-64. e6.

23. Darsow U, Sbornik M, Rombold S, et al. Longterm safety of replication-defective smallpox vaccine (MVA-BN) in atopic eczema and allergic rhinitis. J Eur Acad Dermatol Venereol. 2016;30:1971-7.

24. Davenport J, Gomez R, Smith D. Latex content in adult vaccines. Mil Med. 2020;185:354-5.

25. Prince BT, Mikhail I, Stukus DR. Underuse of epinephrine for the treatment of anaphylaxis: missed opportunities. J Asthma Allergy. 2018;11:143-51.

26. Greenhawt M, Abrams EM, Oppenheimer J, et al. The COVID-19 Pandemic in 2021: Avoiding Overdiagnosis of Anaphylaxis Risk While Safely Vaccinating the World. J Allergy Clin Immunol Pract. 2021;9:1438-41.

27. Mustafa SS, Ramsey A, Staicu ML. Administration of a Second Dose of the Moderna COVID-19 Vaccine After an Immediate Hypersensitivity Reaction With the First Dose: Two Case Reports. Ann Intern Med. 2021(L21):0104 